\title{
What Are the Different Types of Principals Across The U.S.? A Latent Class Analysis of Principal Perception of Leadership Styles
}

\author{
Angela Urick \\ University of Oklahoma \\ Norman, OK, USA \\ urick@ou.edu
}

\author{
Alex J. Bowers \\ Teachers College, Columbia University \\ New York, NY, USA \\ bowers@tc.edu
}

\begin{abstract}
:
Purpose: Effective styles of principal leadership can help address multiple issues in struggling schools, such as low student achievement and high rates of teacher attrition. Although the literature has nominated certain "idealized" leadership styles as being more or less effective, such as transactional, transformational, instructional and shared instructional leadership, we have little evidence about how principals may or may not choose to practice these styles across U.S. schools.

Research Design: Latent class analysis (LCA) was used to identify different types of principals across the U.S. We analyzed the 1999-2000 Schools and Staffing Survey as it presents a unique opportunity to study the different types of U.S. principals since it contains leadership measures not found in other national surveys or administrations. A final sample of 7,650 public schools and principals were included in the analysis.

Findings: Instead of idealized leadership styles signifying variations in practice, the differences between types of principals were defined by the degree of principal and teacher leadership. Further, the school and principal context, such as school size, urbanicity, accountability performance and principal background, helped to predict each of the three significantly different principal types: Controlling, frequent principal leadership, Balkanizing, high degree of leadership shared with teachers, or Integrating, frequent principal leadership as well as a high degree of leadership shared with teachers.

Conclusions: These types suggest that principals simultaneously practice leadership behaviors associated with multiple leadership styles in accordance with their background and school context. These findings provide support for the use of more complex models to assess school leader effectiveness.
\end{abstract}

Keywords: Leadership styles, instructional leadership, transformational leadership, leadership effectiveness, latent class analysis

\section{REVIEW OF LITERATURE}

Over the past two decades, the study of school leadership has shifted from a focus on traditional, top-down forms of instructional leadership to instructional leadership that is shared with teachers (Blase \& Blase, 1999; Hallinger, 2003; Rowan 1990; Spillane,

\footnotetext{
${ }^{1}$ This document is a pre-print of this manuscript, which was originally published in the journal Educational Administration Quarterly: Citation:

Urick, A., Bowers, A.J. (2014) What are the Different Types of Principals Across the U.S.? A Latent Class Analysis of Principal Perception of Leadership. Educational Administration Quarterly, 50(1), 96-134. doi:10.1177/0013161X13489019
}

Urick \& Bowers (2014)
Hallett \& Diamond, 2003). In fact, shared instructional leadership has been found to have the largest leadership effect on student academic growth (Heck \& Hallinger, 2009; Marks \& Printy, 2003; Robinson, Lloyd \& Rowe, 2008). This shift to more collective or distributed leadership promotes a restructuring of schools (Marks $\&$ Louis, 1999). The principal is no longer solely responsible for leading the instructional program within schools but rather the principal provides direction and support to teachers in order to actively distribute this responsibility among these instructional experts. Due to this conception of a restructuring of leadership in schools over time, little is known about the ways in which principals across the U.S. have adjusted their leadership to engage teachers in the practice of school leadership (Harris, Leithwood, Day, Sammons \& Hopkins, 2007; Mayrowetz, 2008; Spillane, Hallett \& Diamond, 2003; Spillane, 2006). To date, while much of the research has focused on teacher perceptions of leadership, little research has been done to examine principal perceptions of their own leadership practice and how those practices, in combination with school context, help to develop school conditions which support the inclusion of teachers as instructional leaders (Urick \& Bowers, 2011, 2014; Evans, in press; Leithwood \& Jantzi, 2008).

\section{Importance of principal perception}

Principal perception and, in turn, principal behavior determine the extent to which school leaders influence organizational change for student improvement. Reviews of the past research on the degree of principal influence on students have shown that principals indirectly affect student learning through teachers (Hallinger \& Heck, 1996; Hallinger \& Heck, 1998). However, principals who decide to develop and share leadership with teachers build school capacity which positively contributes to academic growth (Heck \& Hallinger, 2009; Hallinger \& Heck, 2010; Leithwood \& Mascall, 2008). Furthermore, this change in school capacity serves as a catalyst for additional reciprocal effects from experiencing academic growth to subsequent advances in shared leadership (Hallinger \& Heck, 2011). Principals increase the extent of their influence over school improvement by sharing leadership with teachers.

Although shared instructional leadership operates in a decentralized structure, a principal, in a position of formal authority, guides its development and distributes responsibility to teachers (Leithwood \& Jantzi, 1999; Leithwood \& Jantzi, 2000; Marks \& Louis, 1999, Hallinger \& Murphy, 1986). With this guidance, principal leadership directly influences teacher community as well as instruction (Louis et al., 2010; Supovitz, Sirinides \& May, 2010). Principals improve teacher practice through supportive managerial tasks, such as hiring, spending, and an orderly climate, but more importantly principals shape instruction through the establishment of a school climate and the frequent communication of a common mission and vision 
(Firestone \& Wilson, 1985, Hallinger \& Heck, 2001). Firestone and Wilson (1985) argued for a distinction among the different forms of support principals provide teachers with managerial tasks separate from principal behaviors that build a positive school academic climate.

In more recent studies, leadership behaviors that contribute to a creation of a school climate have been found to have an increased influence on teacher and student outcomes compared to managerial tasks (Hoy \& Hannum, 1997; Hoy, Sweetland \& Smith, 2002; Hoy, Tarter \& Bliss, 1990; Hoy, Tarter \& Woolfolk Hoy, 2006). In a meta-analysis of studies on the impact of different leadership styles on student outcomes, Robinson, Lloyd and Rowe (2008) identified five core measures of effective leadership behaviors which included establishment of goals, promoting and participating in teacher development, planning, coordinating and evaluating instruction and managerial tasks of resourcing and creating a safe and orderly environment. A focus on school climate, goals, coordination of curriculum and promotion of teacher development appear to produce the largest effects on student outcomes (Robinson, Lloyd \& Rowe, 2008). However, out of the 27 studies included in the meta-analysis the majority of measures analyzed were limited to teacher perceptions even though it is the principal and, in turn, principal perception that directs these actions within the school. To date, few studies have investigated leadership styles of principals using principal perception (Urick \& Bowers 2011, 2014; Leithwood \& Jantzi, 2008;). Leithwood and Jantzi (2008) recommend that "subsequent research about leader efficacy [as measured by principal perception of their own leadership] should attend to the stylistic differences in the enactment of core leadership practices" (p. 522).

Principals who perform core leadership behaviors, such as communication of a mission, providing professional development and coordination of instruction, may not apply them to their context with the same technique (Leithwood, Harris \& Hopkins, 2008; Ylimaki \& Jacobson, 2013). Further, principals across different schools who apply these core leadership behaviors with similar tasks or activities produce different results with teachers and students (Hallinger \& Heck, 2010). While we recognize common, basic leadership behaviors, there is evidence to suggest that they are broadly similar across contexts and uniquely defined by the actions that leaders perceive as necessary to respond to specific student, teacher and community needs in order to promote system change (Hargreaves, Halász \& Pont, 2007; Hopkins \& Higham, 2007; Ishimaru, 2012; Leithwood, Patten \& Jantzi, 2010; Moolenaar, Daly \& Sleegers, 2010)

Further investigation into principal perceptions of their leadership would explain the ways in which principals decide to enact these core effective leadership behaviors to navigate their particular context for increased student outcomes through the involvement of teachers in the leadership of a positive school climate. Prominent leadership styles, such as transformational, instructional and shared instructional leadership possibly represent these differences across principals. However, we argue that a conceptual comparison of these leadership styles demonstrates substantial overlap rather than a description of differences in practice.

\section{Transformational leadership}

Transformational leadership in education is often measured by the degree that a principal communicates a mission, encourages development, and builds community (Bogler, 2001; Hallinger, 2003; Leithwood et al., 1998; Nguni, Sleegers \& Denessen, 2006;
Thoonen et al., 2011). With a strong climate that includes a clear mission with support, teachers are motivated to contribute to the improvement of the school (Thoonen et al., 2011). Transformational leadership engages and empowers teacher involvement in school leadership (Geijsel, Sleegers, Leithwood \& Jantzi, 2003). This climate and the involvement of teachers are conditions under which innovation occurs (Bass, 1985; Burns, 1978; Moolenaar et al., 2010). Two main conceptual frameworks of transformational leadership are used in educational research that provide a more detailed description of the ways in which principals have created this climate which leads to teacher involvement and innovation. The concept of transformational leadership was developed in the business literature as a means for transforming organizations (Bass, 1985; Bass \& Avolio, 1993; Burns, 1978) and was transferred into the context of schools as a strategy to support reform (Leithwood, 1994; Leithwood \& Jantzi, 2000).

First, Burns (1978), Bass (1985) and Bass and Avolio (1993) describe transformational leadership as a valuing of organization and members over self, in contrast to transactional leadership, in which leaders attend to managerial tasks. A transformational leader, in opposition to a leader who manages resources and closely monitors staff or fails to intervene (Bass \& Avolio, 1990), instead encourages development and training through "the four I's" which include: individualized consideration (motivates workers with self-worth and recognition to act in the interest of the organization), intellectual stimulation (provides a focus on development), inspirational motivation (builds community and leaders), and idealized influence (builds and engages others in a mission) (Bass, 1985; Bass and Avolio, 1993). These four components guide the restructuring of organizations to develop followers, or teachers, as leaders for increased effectiveness (Bass \& Avolio, 1993).

In the second conceptual framework, Leithwood (1994) and associates (Leithwood \& Jantzi, 2000; Leithwood \& Sun, 2012) extended the conceptualization of transformational leadership for school leaders to six factors: building school vision and goals, providing intellectual stimulation, offering individualized support, modeling professional practices and values, demonstrating high performance expectations, and developing structures to foster participation in school decisions. Leithwood and Jantzi (2000) and Leithwood and Steinbach (1995) emphasize that these transformational leadership behaviors consist of problem-solving processes to further promote organizational change and improvement.

Transformational leadership restructures and prepares schools for an increase in shared leadership with improved opportunities for innovation and change (Bass \& Avolio, 1993, Moolenaar et al., 2010). Principals who are transformational leaders offer teachers a climate with a mission, professional growth and a sense of community. Transformational leadership is focused on developing people and the organization, which improve outcomes (Bogler, 2001; Hallinger, 2003). Nevertheless, for schools, the concept of transformational leadership has been expanded to include added responsibilities for the principal around facilitating the improvement of daily instructional tasks of teachers, known as instructional leadership (Hallinger, 2005)

\section{Instructional leadership}

Instructional leaders work directly with teachers to guide the curriculum and instruction (Cuban, 1984; Edmonds, 1979; Hallinger, 2005). In early research, instructional leaders were 
described as heroic principals who improve failing schools (Edmonds, 1979; Hallinger \& Murphy, 1985). More specifically, Hallinger and Murphy (1985) defined instructional leadership as defining the school mission (setting and communicating goals), managing the instructional program (evaluating instruction, coordinating curriculum and monitoring student progress), and creating a positive school climate (protecting instructional time, promoting professional development, maintaining visibility, and providing incentives). These leadership behaviors closely resemble descriptions of transformational leadership with an expanded focus on the instructional program.

Hallinger $(2003,2005)$ postulated two main differences between instructional and transformational leadership. First, in transformational leadership, teachers and other staff perform instructional tasks as their designated role. Transformational principals do not practice the guidance of curriculum and instruction or monitoring of student learning. Second, transformational leaders spend more time directly building community through support of the needs of teachers and the community, and transfer of school goals to personal goals. Instructional leaders build a positive climate through professional development and coordination and attainment of instructional goals. However, unlike transformational leaders, instructional leaders do not work to build a climate. Instead, in instructional leadership, a positive climate is an indirect result of a common and successful focus on instruction. Shared instructional leadership, which stemmed from critiques of instructional leadership as bureaucratic and principal-centered (Hallinger, 2003; Rowan, 1990), includes more direct measures of the ways in which teacher community and teacher leadership are developed (Printy, Marks \& Bowers 2009; Berliner, 1986; Mangin, 2007; Printy, 2008; Rowan, 1990).

In sum, transformational leadership is a precursor for a distributed (Harris, 2004; Spillane, Halverson \& Diamond, 2004) or shared form of instructional leadership (Printy, Marks \& Bowers, 2009; Marks \& Printy, 2003). Transformational leadership promotes increased engagement of teachers (Marks \& Louis, 1999) while instructional leadership focuses the work of principals and teachers around instruction (Hallinger \& Murphy, 1985; Hallinger, 2003). In contrast, shared instructional leadership promotes the collaboration of principals and teachers around instruction (Printy, Marks \& Bowers, 2009; Marks \& Printy, 2003).

\section{Shared instructional leadership}

Shared instructional leadership is described as a "synergistic power of leadership shared by individuals through the school organization" (Marks \& Printy, 2003, p. 393). This synergy around instruction among principals, teachers and the school community is created through a mixture of leadership behaviors that have been associated with instructional leadership, transformational leadership, and shared instructional leadership. In school effectiveness research, this synergy is measured by factors that support successful teacher practice. For example, principals who build a positive climate for teachers through communication of a mission, shared decisions, supportive professional development, a sense of teacher community and public relations with the broader community, promote an environment in which teachers feel empowered and committed (Bryk et al., 2010; Marks \& Louis, 1999; Moolenaar, Daly \& Sleegers, 2010; Muijs \& Harris, 2003; Printy, 2008; Thoonen, Sleegers, Oort, Peetsma \& Geijsel, 2011; Ware \& Kitsantas, 2011; Zembylas \& Papanastasiou, 2005). This teacher commitment and empowerment generated from effective leadership behaviors has been found to increase performance and student achievement (Bryk et al., 2010; Somech, 2005; Zigarelli, 1996). Further, teachers who are empowered and committed within their position are less likely to leave their job (Guarino, Santibanez \& Daley, 2006), which builds a stable community of effective teacher leaders (Ingersoll, 2001). When principals gain synergy within the school, capacity is developed through teacher empowerment and the experience of continued success and reciprocal effects (Hallinger \& Heck, 2011; Marks \& Louis, 1999; Slater, 2008; Somech, 2005; Thoonen et al., 2011).

Marks and Printy (2003) concluded that this synergy is derived from what they termed integrated leadership. Using a sample of 24 restructured elementary, middle and high schools, the authors used surveys, interviews and observations to measure the degree of both transformational and shared instructional leadership within each school. To investigate the relationship between transformational and shared instructional leadership, they plotted the standardized mean scores of shared instructional leadership by transformational leadership. By graphing the relationship among both leadership styles at each school, they found that principals who practiced high shared instructional leadership also exhibited high transformational leadership. Absent from this analysis were principals who were able to practice shared instructional leadership without demonstrating behaviors of transformational leadership, demonstrating that transformational leadership was necessary but insufficient for shared instructional leadership. The authors assigned the term "integrated leadership" to schools that exhibited both transformational and shared instructional leadership.

To test the effect of integrated leadership on academic outcomes, Marks and Printy (2003) used hierarchical linear modeling to demonstrate the amount of variance explained in pedagogical quality and authentic achievement with integrated leadership. They found that average standardized achievement and integrated leadership explained $26 \%$ of the variance in pedagogical quality and student standardized achievement, student ethnicity and integrated leadership explained $57 \%$ of the variance in authentic achievement. These findings from Marks and Printy (2003) help to explain the importance of a multi-leadership style approach in order to better understand the ways in which principals develop shared instructional leadership.

Principals who practice integrated leadership through combining the aspects of transformational and shared instructional leadership, create a synergy among teachers and principals around instruction that supports innovation and change (Marks \& Printy, 2003; Moolenaar, Daly \& Sleegers, 2010; Thoonen, Sleegers, Oort, Peetsma \& Geijsel, 2011). Transformational leadership provides particular strategies for building an overall positive climate through a mission, professional growth and a sense of community (See Table 1). Similar leadership behaviors have been represented in both instructional and shared instructional leadership (represented by arrows across columns in table 1). Instructional leadership takes a more indirect or top-down approach to building this climate with high visibility of principal and offering of rewards (compare text across build sense of community row in table 1). Yet, instructional leadership adds the coordination of the instructional program not found in transformational leadership. The same focus on the coordination of the instructional program is transferred to shared instructional leadership (represented by arrows across columns). However, shared instructional leadership more accurately represents the original intent of transformational 
Table 1: Conceptual framework of different leadership styles of principal behavior

\begin{tabular}{|c|c|c|c|}
\hline $\begin{array}{l}\text { Core Leadership } \\
\text { Behaviors }\end{array}$ & $\begin{array}{c}\text { Transformational Leadership } \\
\text { (Bass \& Avolio, 1994; Leithwood, } \\
\text { 1994; Leithwood \& Sun, 2012) }\end{array}$ & $\begin{array}{c}\text { Instructional } \\
\text { Leadership } \\
\text { (Hallinger \& Murphy, 1985) }\end{array}$ & $\begin{array}{c}\text { Shared Instructional } \\
\text { Leadership } \\
\text { (Printy, Marks \& Bowers, } \\
\text { 2009; Marks \& Printy, 2003) }\end{array}$ \\
\hline $\begin{array}{l}\text { Communicate } \\
\text { mission }\end{array}$ & $\begin{array}{l}\text { Inspirational motivation, } \\
\text { Idealized influence; build } \\
\text { school vision and goals, } \\
\text { demonstrate high performance } \\
\text { expectations }\end{array}$ & $\begin{array}{l}\text { Articulate and } \\
\text { communicate clear } \\
\text { school goals, high } \\
\text { expectations }\end{array}$ & $\begin{array}{l}\text { Strong principal } \\
\text { leadership to facilitate } \\
\text { growth and direction }\end{array}$ \\
\hline $\begin{array}{l}\text { Promote } \\
\text { professional } \\
\text { growth }\end{array}$ & $\begin{array}{l}\text { Individual consideration, } \\
\text { intellectual stimulation; provide } \\
\text { intellectual stimulation, offer } \\
\text { individualized support }\end{array}$ & $\begin{array}{l}\text { Promote professional } \\
\text { development for teachers }\end{array}$ & $\begin{array}{l}\text { Provide opportunities for } \\
\text { teacher growth }\end{array}$ \\
\hline $\begin{array}{l}\text { Build sense of } \\
\text { community }\end{array}$ & $\begin{array}{l}\text { Idealized influence, intellectual } \\
\text { stimulation; rewards; symbolize } \\
\text { professional practices and } \\
\text { values, provide intellectual } \\
\text { stimulation, develop structures } \\
\text { to foster participation in school } \\
\text { decisions }\end{array}$ & $\begin{array}{l}\text { Maintain high visibility, } \\
\text { provide incentives for } \\
\text { teachers, provide } \\
\text { incentives for learning }\end{array}$ & $\begin{array}{l}\text { Principal and teachers } \\
\text { discuss alternatives for } \\
\text { instructional practices }\end{array}$ \\
\hline $\begin{array}{l}\text { Coordinate the } \\
\text { instructional } \\
\text { program }\end{array}$ & & $\begin{array}{l}\text { Coordinate curriculum, } \\
\text { evaluate instruction, } \\
\text { monitor student progress, } \\
\text { protect instructional time }\end{array}$ & $\begin{array}{l}\text { Maintain congruency of } \\
\text { educational program }\end{array}$ \\
\hline $\begin{array}{l}\text { Share instructional } \\
\text { leadership with } \\
\text { teachers }\end{array}$ & & & $\begin{array}{l}\text { Teachers responsibility for } \\
\text { change, leadership roles } \\
\text { for teachers }\end{array}$ \\
\hline
\end{tabular}

leadership through the inclusion of teachers in the building of community and climate (compare text in build sense of community row in table 1). Uniquely, shared instructional leadership contributes that teachers share responsibility for organizational change and leadership around instruction. This comparison of leadership styles demonstrates the considerable amount of overlap among leadership styles. To date, we have little evidence about the different ways in which principals across the U.S. decide to enact these effective leadership behaviors to promote innovation and change that is appropriate for their schools' needs.

The last couple decades of research on principal leadership has identified a core set of effective leadership behaviors and demonstrated how these behaviors group together in different ways to collectively describe several leadership styles. As a result, we know that principals of an average U.S. school who perform all of these core leadership behaviors, which best describe shared instructional leadership, promote the greatest increase in student outcomes (see Robinson, Lloyd \& Rowe, 2008). However, this line of inquiry has focused on the effectiveness of these behaviors rather than the principal, who is able to perform or not perform these behaviors (Leithwood \& Jantzi, 2008; Urick \& Bowers, 2011, 2014), and the school context, in which the characteristics, for example, student demographics, school location, grade level, influence the effectiveness of these behaviors differently (Louis et al., 2010; May, Huff \& Goldring, 2012). Our conceptualization of types, the grouping of principals, compared to styles, the grouping of behaviors, better accounts for the differences in the way that principals may or may not perform these idealized behaviors in their specific school context (Fielder, 1966; 1967; 1978; Miller \& Rowan, 2006).

\section{Principal typologies}

The role of principals in school leadership has shifted from a sole focus on principals building a community, a mission and professional growth, transformational leadership, to an additional focus on principals leading the instructional program and sharing these tasks with teachers, shared instructional leadership. However, while researchers have urged school leaders to take up the mantel of shared instructional leadership, currently there is little data on the different ways in which principals actually practice leadership in schools, i.e. types of principals.

Samples to date across the past literature have been based on a limited number of principals or school contexts, or informative but intact sample qualitative case studies. Little evidence exists to 
explain the ways in which transformational, instructional or shared instructional leadership are or are not practiced across U.S. schools. Further, given the previous overlap among leadership styles (see also Leithwood \& Sun, 2012), a principal could simultaneously practice several styles, particularly transformational and shared instructional leadership (Marks \& Printy, 2003). No study to date has examined the different types of principals based on perceptions of their own leadership styles. More evidence is needed to describe the types of leaders that exist and how these different types align with current conceptions of transformational, instructional and shared instructional leadership using a large generalizable sample rather than evidence that urges principals to practice one leadership style over another.

Only one study has attempted to identify different types of principals while accounting for school context. The inclusion of school context variables is important since a principal adjusts their leadership to meet the needs of the teachers and students within the school (Hallinger, Bickman \& Davis, 1996; Slater \& Teddlie, 1992). Goldring, Huff, May and Camburn (2007) used cluster analysis to identify different types of principals in one school district based on principal logs of their time allocations. The authors found three different types of leaders: eclectic principals, instructional principals and student-centered principals. In a subsequent analysis, they predicted different leadership behaviors with contextual variables to show the magnitude of each contextual variable on the leadership behaviors of each principal type. They showed that eclectic principals came from less disadvantaged schools with more free time to spend on a variety of leadership activities. Student-centered and instructional principals worked in schools with more economically disadvantaged students with their behaviors reflecting multiple accountability and context-focused pressures. The authors concluded that the school context was crucial to help predict the different ways in which principals decided to lead their school. This study provides evidence that the different types of principals in schools do not necessarily align with previous conceptions of leadership styles.

The study of principal typologies adds to the current literature by providing an explanation of the different ways in which principals choose to lead in various school contexts. However, cluster analysis, used by Goldring, Huff, May and Camburn (2007), does not incorporate a hypothesis test of the number of significantly different types present in the data. In addition, cluster analysis does not allow for the inclusion of school context variables as predictors in an omnibus model. The emerging field of mixture models and latent class analysis (Hallinger \& Heck, 2011; Muthén \& Asparouhov, 2006; Muthén \& Muthén, 2000) more appropriately models significantly different variations in data with the opportunity to include background characteristics as independent variables. This methodology fits with the call from Hallinger and Heck (2011) to use more complex models to examine school processes.

We argue that principal perception demonstrates the ways in which principals choose to perform or not perform idealized core leadership behaviors, or groups of behaviors, styles, within their own school. In order to appropriately test for the complex differences of leaders across various U.S. contexts, we seek to identify types or subgroups of principals based on the similarities and differences of how they perceive their own leadership while accounting for principal background, such as gender and experience, as well as school characteristics.
Therefore, the present study uses latent class analysis to identify the different types of principals present in US schools using principal perceptions of leadership styles such as managerial tasks, transformational leadership, instructional leadership and shared leadership, while accounting for school and principal background variables. The purpose of this study is to identify different types of principals across the U.S. and to test the extent that principal and school characteristics predict these types. This study addresses the following research questions:

1. What are the different types of principals across U.S. schools based on their perceptions of their own leadership styles?

2. To what extent do school context and principal background characteristics predict these principal types?

3. In what way do these different types of principals demonstrate a two dimensional relationship between transformational and shared instructional leadership as proposed by Marks and Printy (2003)?

\section{METHODS}

\section{Sample}

This study is a secondary analysis of the restricted-use 1999-2000 Schools and Staffing Survey (SASS), originally collected by the National Center for Education Statistics (NCES). In 1999, NCES collected data on about 9,890 schools in the U.S. (NCES, n.d.). In SASS, schools are the primary sampling unit (Gruber et al., 2002; NCES, n.d.). The sample design estimates school characteristics by the nation, elementary and secondary levels, public and private sectors, Bureau of Indian Affairs (BIA) schools and schools with American Indian or Alaska Natives, school levels by states and private schools by association, region and school level (Gruber et al., 2002; NCES, n.d.). From the 1997-98 Common Core of Data (CCD), public schools were selected to represent national and state characteristics (Gruber et al., 2002). Districts (or LEAs) and principals were sampled from these selected schools. Weights are provided to adjust for the probability of selection and to account for the sample of cases eligible but not surveyed (Gruber et al., 2002).

SASS provides a unique opportunity to connect school and principal characteristics to leadership perceptions with nationally generalizable data (Gruber et al., 2002). More specifically, the 1999-2000 SASS principal survey includes school leadership variables no longer found in more recent administrations of SASS. These items consist of the frequency that a principal facilitates an achievement of a school mission, guides the development and evaluation of curriculum, and builds a professional community among faculty and staff, which are instrumental measures in the representation of the prominent leadership styles found within the literature. We used a final sample of $n=7,650$ public schools and principals from SASS. To maintain confidentiality, sample sizes are rounded to the nearest ten.

\section{Variables included in the analysis}

Principal perception. Based on prior descriptions of leadership styles, principal perception variables were selected for inclusion in the analysis. There were two main groups of variables. First, principals responded to items about their own leadership. Second, principals responded to items about the extent that leadership was shared with teachers. Since the principals' perception about their own leadership did not contain a neutral response, eleven items were dichotomized to simplify the model. In addition, two additional continuously scaled items were included in the 
typology, principal perception of social disorder and percent of faculty teaching to high standards. For principal perceptions about teachers, seven items of principal perceptions about shared leadership with teachers remained as a five-choice Likert scale.

Principals responded to survey items about the frequency of their behaviors which align with the descriptions of transformational leadership, instructional leadership and managerial tasks in previous literature. As detailed in Appendix 1, Transformational leadership was measured by whether principals view themselves as attending professional development with teachers $(0=$ never to twice, $1=$ three to six or more times), developing public relations, facilitating achievement of school mission, building professional community, providing professional development activities either seldom $(0=$ never to once or twice a month $)$ or frequently $(1=$ once or twice a week to daily) (Bass \& Avolio, 1993; Bogler, 2001; Geijsel, Sleegers, Leithwood \& Jantzi, 2003; Hallinger, 2003; Leithwood et al., 1998; Nguni, Sleegers \& Denessen, 2006; Thoonen et al., 2011). Instructional leadership was measured by whether principals view themselves as guiding development of curriculum and facilitating student learning either seldom $(0=$ never to once or twice a month) or frequently $(1=$ once or twice a week to daily) (Cuban, 1984; Edmonds, 1979; Hallinger, 2003, 2005). Managerial tasks were measured by whether principals view themselves as maintaining physical security, managing school facilities, supervising staff, attending district meetings either seldom $(0=$ never to once or twice a month) or frequently ( 1 $=$ once or twice a week to daily) (Bass, 1985; Firestone \& Wilson, 1985). In addition, to describe their need for these managerial tasks, principals were asked to rate the degree of social disorder $(0$ $=$ not a problem to $4=$ serious problem) within their schools, which included student tardiness, student absenteeism, class cutting, physical conflicts, theft, vandalism, alcohol use, drug abuse, weapons, and disrespect for teachers $(\alpha=.85)$ (Griffith, 1999). Finally, principals suggested the percentage of faculty teaching to high standards (Kennedy, 2006) (see Appendix 2).

Principals responded to survey items about the degree of influence $(0=$ no influence to $4=$ a great deal of influence) teachers had over instructional leadership as well as managerial tasks, presented in Appendix 3. The amount of instructional leadership shared with teachers was measured by the degree that teachers set performance standards for students in the school, established curriculum at school, and determined the content of in-service professional development programs for teachers in school (Printy, Marks \& Bowers, 2009; Hallinger, 2003, 2005; Harris, 2004; Marks \& Printy, 2003; Spillane, Halverson \& Diamond, 2004). The degree of shared influence with teachers over managerial tasks included evaluating teachers in this school, hiring teachers, deciding how the budget will be spent and setting discipline policy for the school (Bridges, 1967; Smylie \& Brownlee-Conyers, 1992; Weiss, 1993).

School context. As detailed in Appendix 3, school demographics, accountability context and principal background were selected as predictors of the principal types. School demographics included urbanicity, school size, grade level, percent of students who receive special support (ELL, IEP), percent of minority students and teachers, and student/teacher ratio which have been found to influence school leadership (Hallinger, Bickman \& Davis, 1996; Louis et al., 2010). Whether or not the school met state and/or district goals for the previous school year was incorporated as a measure of the current accountability context of the school which relates to leadership decisions and effectiveness (Hallinger \& Heck, 2011; Weathers, 2011). Lastly, principal gender, ethnicity, highest level of education, years of experience as a principal and years of experience as a teacher were included in the model (White \& Bowers, 2011; Hallinger, Bickman \& Davis, 1996; Louis et al., 2010) (refer to Appendix 1, 2, 3 for all variables names and descriptives).

\section{Analytical model}

Latent class analysis (LCA) has recently emerged from the broader mixture and structural equation modeling literature as a useful method for examining if a typology exists within a dataset, and to what extent different subgroups pattern into each group while accounting for multiple covariates (Bowers \& Sprott, 2012a, 2012b; McCutcheon, 2002; Muthén, 2008; Dolan, 2009; Duncan, Duncan \& Stryker, 2006; Goodman, 2002; Hallinger \& Heck, 2011;). Much like cluster analysis, LCA takes a set of survey items as the dependent variables and determines the extent to which different groups of respondents are similar or different across the items in order to assign each participant to a like subgroup or latent class. However, LCA has been shown to be superior to cluster analysis in that LCA provides a hypothesis test for the number of subgroups as well as allows for an omnibus model, which includes a simultaneous multinomial logistic regression to examine the extent that covariates influence the subgroups. In a structural equation model framework, a set of independent variables, such as principal background or school characteristics, explain the latent classes, types of principals as the mediated variable, which are identified by a set of survey items, principal perceptions of leadership as the dependent variables (Muthén, 2002; 2003; 2004; 2008). This method is well suited to examine the number of different types of principals based on their perceptions of their own leadership styles across U.S. schools and the extent that school context variables predict these types.

For the present study, we used Mplus version 6 to estimate a latent class analysis (LCA) model using Robust Maximum Likelihood (MLR) estimation (Muthén \& Muthén, 1998-2010). The dependent variables that define the different subgroups, or "latent classes", were organized into two main conceptual categories as described above: principal perception of principal leadership - managerial tasks, transformational leadership, instructional leadership - and principal perception of shared leadership with teachers managerial tasks and instructional leadership (see Figure 1). School and principal context and background variables, as well as the accountability variable school met district or state goals were included as independent variables in the model.

The labels for the principal perception of leadership variables, managerial tasks, transformational leadership and instructional leadership, were used only as a form of organization to bring order to the list of behaviors so that they easily link to past literature and aid in the interpretation of results. From our review of literature, we argue that these leadership styles have substantial conceptual overlap and may not represent the difference between principals. For this reason, the behaviors that might commonly describe these styles were entered into the model separately, not as composites from factor analysis, so that the latent class analysis results could demonstrate the variation in principals' responses to each of these behaviors across the significantly different principal types. We know from previous research the extent of the relationship, dimensionality and reliability of scales of the 1999-2000 SASS survey items and specifically, these principal perceptions of leadership variables (e.g. Marks \& Nance, 2007; Ware \& Kitsantas, 2007; 2011; Wolfe, Ray \& Harris, 2004). An examination of correlations or psychometric properties was beyond 
Context Variables

\begin{tabular}{|l|}
\hline School \\
Urban \\
Rural \\
Small enrollment \\
Large enrollment \\
Extra large enrollment \\
Elementary level \\
Percent of students with IEP \\
Percent of ELL students \\
Percent of students eligible for \\
FRPL \\
Percent of minority students \\
Percent of minority teachers \\
Student/Teacher ratio \\
Accountability \\
School met district or state goals \\
\hline Principal \\
\hline Female \\
Asian \\
African American \\
Hispanic \\
degree \\
\hline
\end{tabular}

Principal Perception of Principal Leadership

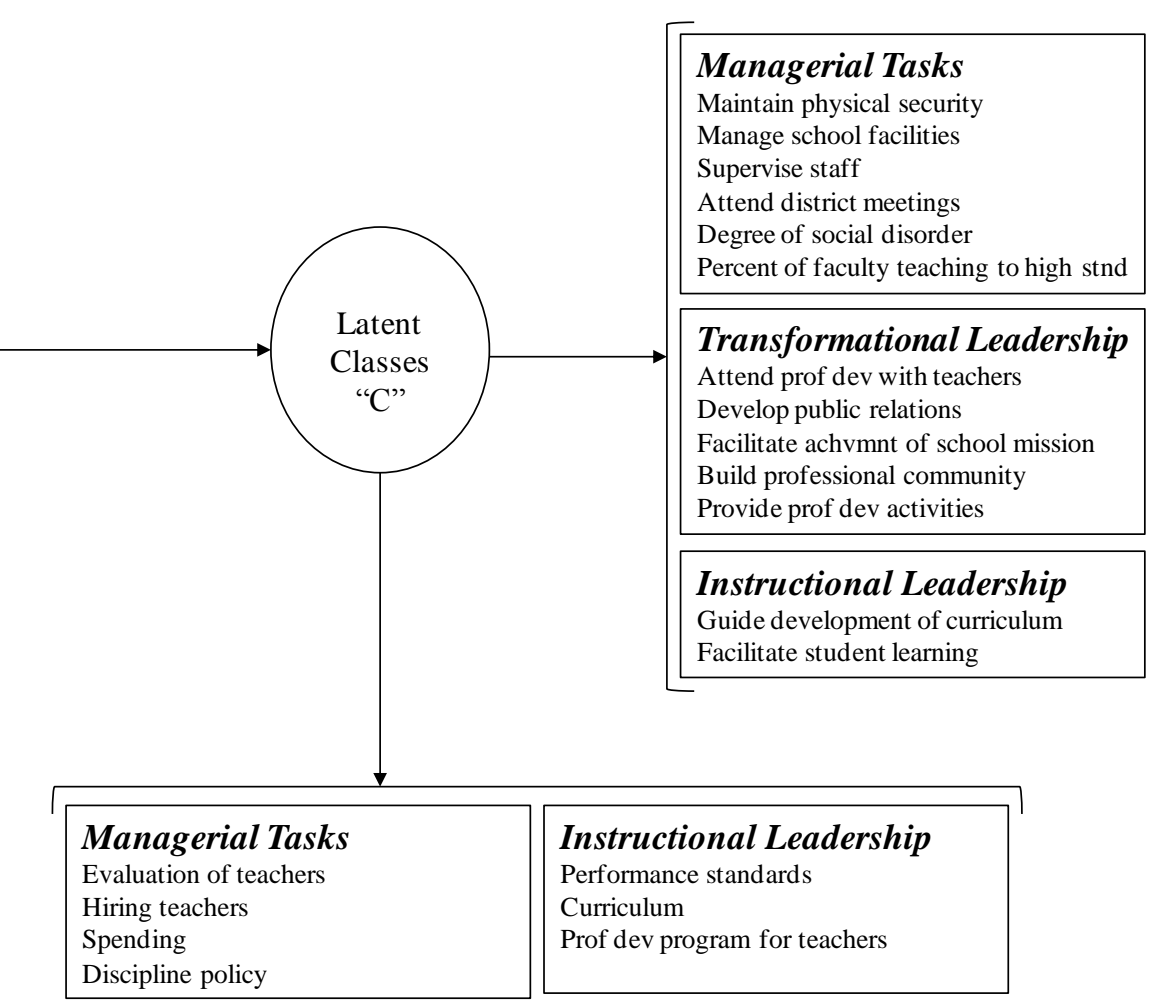

Principal Perception of Shared Leadership with Teachers

\section{Figure 1: Model of latent class analysis (LCA) of principal perception of leadership}

the purpose and statistical procedures of this study. Instead, we are interested in the non-parametric nature or frequency of item responses to distinguish between subgroups or types of principals (see McCutcheon, 1987).

In LCA, an iterative set of models is tested (Nylund et al., 2007; Jung \& Wickrama, 2008) in which the first model is a single group model (i.e. to test the hypothesis that there is one type of principal), and then subsequent models are fit to the data, and model fit is assessed using a $k-1$ hypothesis test, the Lo-MendellRubin (LMR) (Lo, Mendel \& Rubin, 2001; Lo, 2005), along with negative loglikelihood, Akaike Information Criteria (AIC), and Bayesian Information Criteria (BIC). Model testing then proceeds iteratively with $k+1$ latent classes (i.e. 2 types, 3 types, 4 types) until the model does not statistically significantly fit, at which point the statistically significant $k-1$ model with the most latent classes is interpreted (Nylund et al., 2007; Jung \& Wickrama, 2008). It is important to note that these iterative models are used determine the number of classes that best fit the data. Only the model with the best fit is interpreted and all parameters are included when testing each number of classes unlike a stepwise regression. Additionally, because SASS is not a simple random sample, but is a probabilistic complex sample representative of the U.S., we applied the sampling weight (AFNLWGT) to the LCA to allow for generalizations to the entire U.S. population of school principals in 1999-2000. Weights correct the standard error from sampling bias for each respondent of a subgroup within a unit, which, if underestimated, increases the probability of a false rejection of a null hypothesis (Stapleton, 2002; Stayhorn, 2009). The benefit of the SASS probabilistic complex sample with respondent (principal) weights applied is that the data is nationally representative of principals and schools, and the results are generalizable.

As a product of the latent class analysis, each participant is assigned to the most likely class or type. Using these assignments, we then returned to the raw data to compare their survey responses by type. Means across the groups were plotted in two ways to aid in visualizing and interpreting the results. First, plots compare mean survey item responses across the different subgroups for principal perception of their leadership and leadership shared with teachers. Second, in order to compare the results of this study to previous research on shared instructional leadership as an integration of shared instructional and transformational leadership (Marks \& Printy, 2003), standardized mean scores of transformational (principal perception of principal transformational leadership) and shared instructional leadership (principal perception of principal and teacher instructional leadership) measures were generated and then plotted to visualize the relationship of these two dimensions for each principal type identified in the LCA.

\section{RESULTS}

Following the recommendations of the mixture modeling literature (Jung \& Wickrama, 2008), we tested an iterative set of LCA models (see Table 2). The four-class model did not significantly fit 
Table 2: Latent class analysis results and fit indices

\begin{tabular}{|c|c|c|c|c|c|c|}
\hline Model & $A I C$ & $B I C$ & $\begin{array}{c}\text {-Loglikelihood } \\
(-L L)\end{array}$ & $\begin{array}{c}\text { \% Decrease } \\
\text { in }-L L\end{array}$ & $\begin{array}{c}\text { Lo-Mendell- } \\
\text { Rubin Test for } \\
\text { k-1 classes }\end{array}$ & $p$-value \\
\hline One-class & 926949.62 & 927436.11 & 463405.81 & --- & --- & --- \\
\hline Two-class & 302142.82 & 302628.80 & 151001.41 & 67.41 & 9758.83 & $<0.001$ \\
\hline Three-class & 297100.82 & 297871.45 & 148439.41 & 67.97 & 5104.97 & $<0.001$ \\
\hline Four-class & 295129.86 & 296185.13 & 147412.93 & 68.19 & 2045.34 & 0.325 \\
\hline
\end{tabular}

the data $(p=0.325)$. The three-class model fit the data well, $\mathrm{p}<0.001$, with an entropy of 0.788 , AIC $=297100.82$, BIC $=$ 297871.45, and LMR=5104.97, so we interpreted the three-class model. Consequently, as the first study to date to examine the prevalence of different types of principals using a large nationally generalizable sample, our results show that schools in the 19992000 academic year had three significantly different types of principals based on their perceptions of their own leadership style in the school and their perceptions of leadership shared with teachers in their school.

After reviewing the differences in principal responses to the survey items and the extent that background and context variables influenced each subgroup, we labeled the three types of principals as Integrating, Controlling, or Balkanizing, to describe the different types of leadership that these principals saw themselves as providing their schools. The majority of the sample (53.93\%) was identified as an Integrating principal. The remaining portion of the sample was split between the Controlling (24.07\%) and Balkanizing (22.0\%) subgroups. We returned to the raw data once each principal was assigned to their most likely class to examine the different patterns of responses by each class. We named the groups based on these differences across their raw responses as well as the extent that particular principal and school background variables helped to predict the membership of principals in each type from the omnibus LCA model. The Integrating principals, the highest responders, were named based on Marks \& Printy (2003). Marks and Printy (2003) describe integrated leadership as principals who utilize multiple styles to ultimately build a synergy between themselves and teachers. Controlling, more frequent principal leadership, and Balkanizing principals, less frequent principal leadership and more frequent leadership shared with teachers, were named to reflect the more nuanced differences beyond their position as mid and low responders since the pattern of mid and low was not consistent for these types across all leadership items as often found in other latent class analysis results (e.g. Nylund, Bellmore, Nishina, Graham, 2007). The differences in their responses about their own leadership and leadership shared with teachers as well as background and school characteristic variables that significantly predicted each type further detail the intended meaning behind these names.

Figure 2 and Figure 3 disaggregate the raw responses of the principals to the survey items by each of the three subgroups. In Figure 2, differences across the survey items by each of the three groups in the principal's perception of their leadership are presented. The Integrating subgroup had the highest principal responses to the frequency of how often they practiced managerial tasks, transformational and instructional leadership. In comparison, the Controlling principals' perceptions of how often they practiced each of the leadership domains were between the Integrating and Balkanizing. The Balkanizing principals had a somewhat different pattern to their responses, responding that they practiced managerial, transformational and instructional leadership tasks less of the time than the Integrating and Balkanizing principals. Less than half of the Balkanizing principals responded that they practiced transformational and instructional leadership behaviors at least weekly.

Figure 3 presents the raw responses across the three groups to the survey items that measured principal perception of shared leadership with teachers. Again, the Integrating subgroup of principals responded that teachers had the highest levels of influence on school decisions in both managerial tasks and instructional leadership. However, in comparison to Figure 2 which examined the principal's perception of their own leadership, Figure 3 shows the opposite pattern from Figure 2 in the Balkanizing and Controlling principal's responses to the amount of leadership that they perceive that teachers have influence over in their schools in both managerial tasks and instructional leadership. Here in Figure 3, the Balkanizing subgroup lies between Integrating and Controlling (the opposite of Figure 2), indicating that when it comes to the degree of influence that the principals share with teachers, the subgroup that we have termed as Balkanizing had fairly high responses to the amount of teacher influence over leadership in their schools, while the Controlling group saw teachers in their schools as having the lowest levels of influence, especially when it came to influence over instructional leadership issues such as performance standards, curriculum and professional development (see Figure 3, right).

In addition, the typology varied across the principal's raw responses to percent of teachers teaching to high academic standards $(\mathrm{F}=181.59, \quad p<0.001)$ with Integrating principals reporting that $84.03 \%(\mathrm{SD}=13.85)$ of their teachers teach to high academic standards, in comparison with $77.45 \%(\mathrm{SD}=17.90)$ for Balkanizing and $75.31 \%(\mathrm{SD}=18.16)$ for Controlling. Finally, in examining the principal's perception of the amount of social disorder in the school, the three subgroups differed significantly $(\mathrm{F}=77.40, p<0.001)$. Integrating principals perceived the least amount of social disorder $(\mathrm{M}=0.64, \mathrm{SD}=0.48, \mathrm{~F}=77.402, p<0.001)$ while Balkanizing $(\mathrm{M}=0.76, \mathrm{SD}=0.44)$ and Controlling $(\mathrm{M}=0.77$, $\mathrm{SD}=0.47$ ) principals did not differ by social disorder.

In sum, Integrating principals reported more often weekly practice of managerial tasks, transformational leadership and instructional leadership and the greatest degree of teacher influence over managerial tasks and instructional leadership. This dual attention to both their leadership practice and the shared leadership practices of teachers define the Integrating principal type. Controlling 


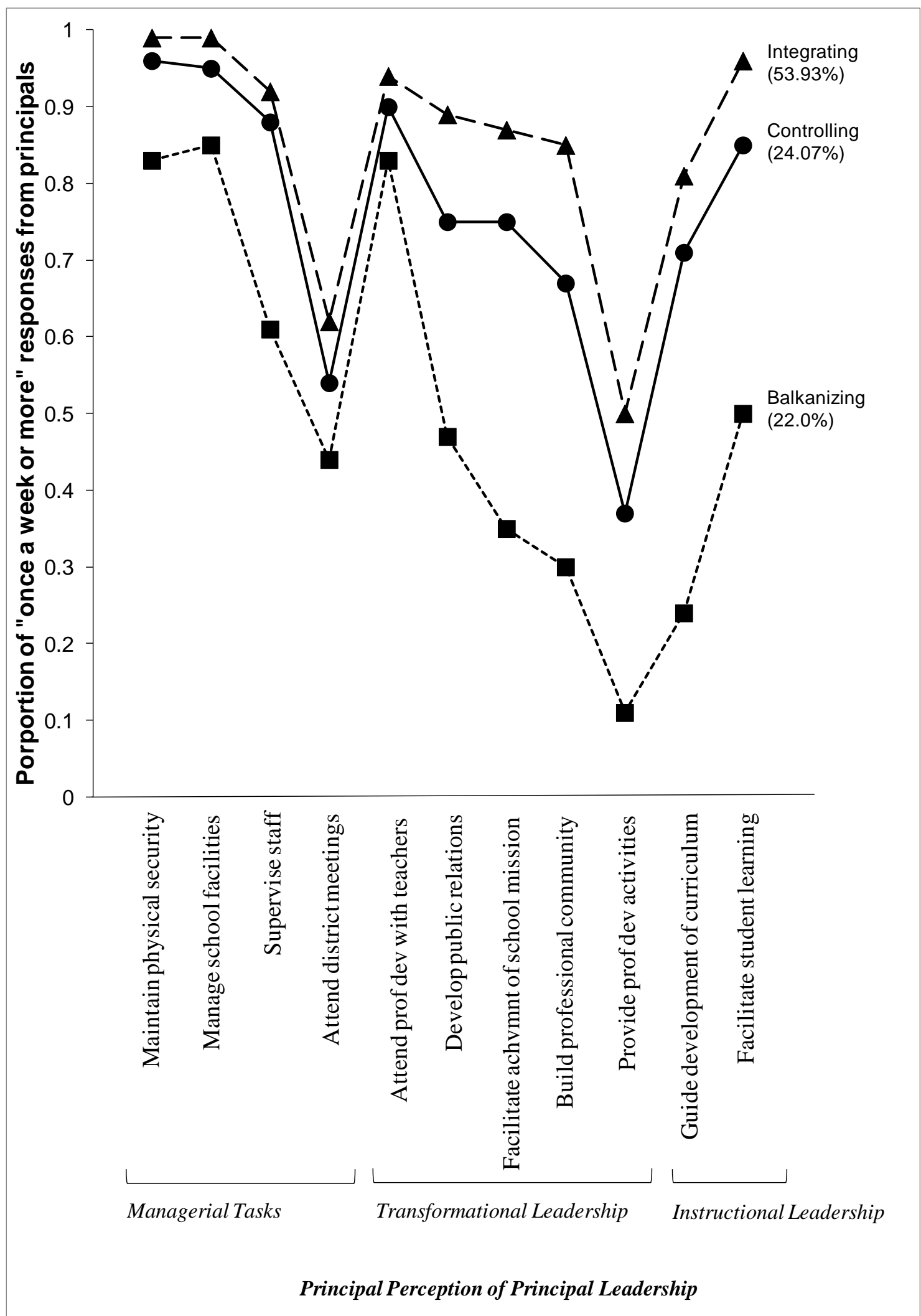

Figure 2: Plot of the proportion of principals in each type who responded that they perform managerial tasks, transformational and instructional leadership tasks at least once a week. 


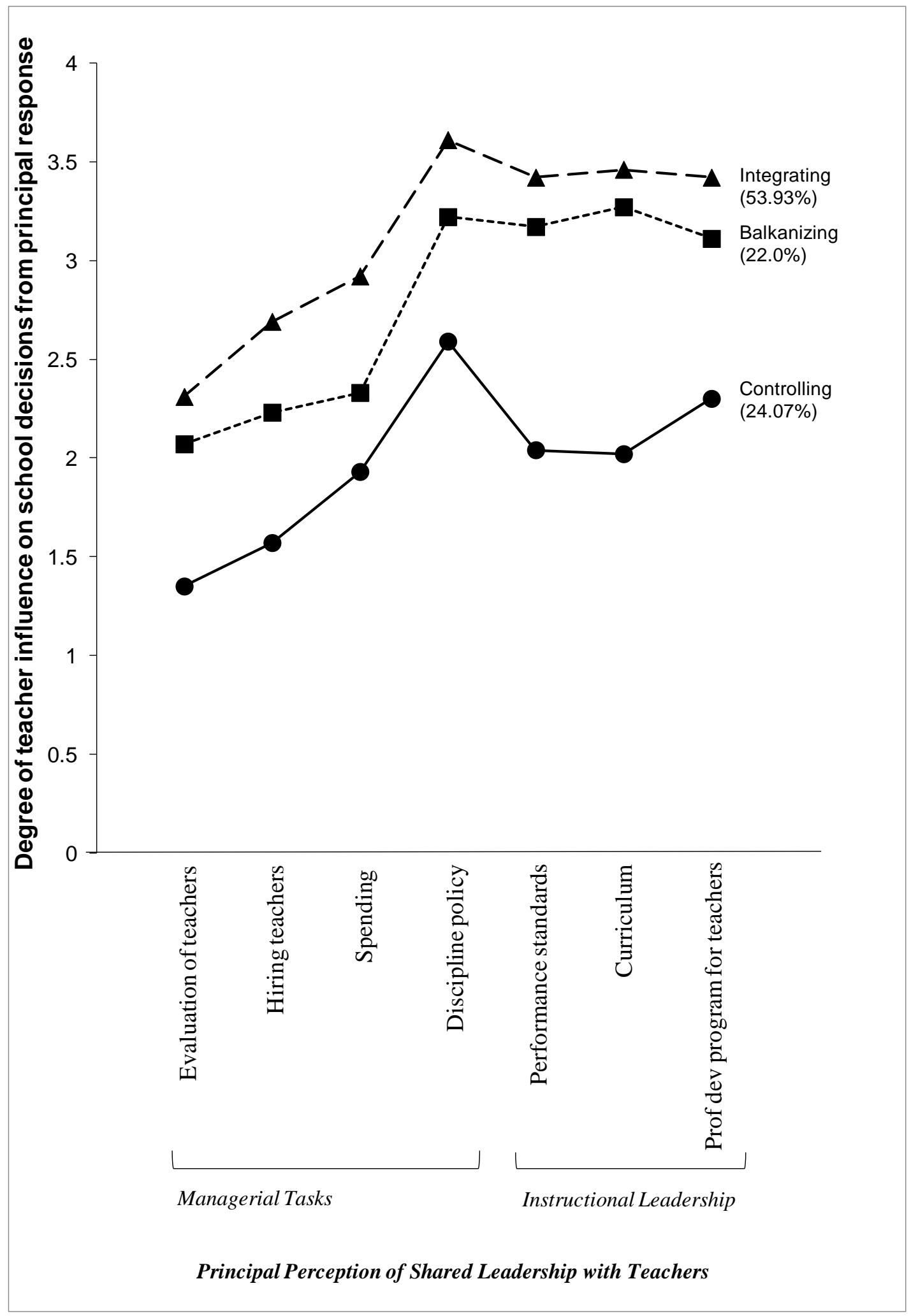

Figure 3: Plot of the mean response of the degree to which the principals in each type perceive that they share managerial tasks and instructional leadership tasks with teachers. 
Table 3: Means and odds ratios for LCA background variables with Integrating class as the reference group.

\begin{tabular}{|c|c|c|c|c|c|c|c|c|}
\hline \multirow[b]{2}{*}{ Variable } & \multicolumn{2}{|c|}{$\begin{array}{c}\text { Balkanizing } \\
22.0 \%\end{array}$} & & \multicolumn{2}{|c|}{$\begin{array}{c}\text { Controlling } \\
24.07 \%\end{array}$} & & \multicolumn{2}{|c|}{$\begin{array}{c}\text { Integrating } \\
53.93 \%\end{array}$} \\
\hline & Mean & Odds Ratio & & Mean & Odds Ratio & & Mean & Odds Ratio \\
\hline \multicolumn{9}{|l|}{ School Demographics } \\
\hline Urban & 0.15 & 0.88 & & 0.29 & 0.97 & & 0.25 & --- \\
\hline Rural & 0.46 & 1.40 & $* *$ & 0.27 & 0.94 & & 0.28 & --- \\
\hline Small enrollment & 0.76 & 1.50 & $* *$ & 0.62 & 0.88 & & 0.67 & --- \\
\hline Large enrollment & 0.04 & 1.42 & & 0.07 & 1.48 & & 0.04 & --- \\
\hline Extra large enrollment & 0.02 & 1.42 & & 0.02 & 0.92 & & 0.02 & --- \\
\hline Elementary level & 0.53 & 0.73 & & 0.57 & 0.87 & & 0.65 & --- \\
\hline Percent of students with IEP & 12.75 & 1.00 & & 12.95 & 1.00 & & 12.70 & --- \\
\hline Percent of ELL students & 4.08 & 1.01 & & 6.03 & 1.00 & & 5.93 & --- \\
\hline Percent of students eligible for FRPL & 38.79 & 1.00 & & 45.54 & 1.00 & & 41.14 & --- \\
\hline Percent of minority students & 22.50 & 0.99 & $* *$ & 39.53 & 1.01 & & 33.03 & --- \\
\hline Percent of minority teachers & 9.28 & 1.00 & & 17.75 & 1.00 & & 14.99 & --- \\
\hline Student/teacher ratio & 14.66 & 0.97 & & 15.39 & 0.98 & & 16.09 & --- \\
\hline \multicolumn{9}{|l|}{ Accountability Context } \\
\hline School met district or state goals & 0.52 & 0.55 & $* * *$ & 0.56 & 0.71 & $* * *$ & 0.65 & --- \\
\hline \multicolumn{9}{|l|}{ Principal Background } \\
\hline Female & 0.32 & 0.59 & $* * *$ & 0.40 & 0.62 & $* *$ & 0.49 & --- \\
\hline Asian & 0.01 & 2.74 & & 0.00 & 0.33 & & 0.01 & --- \\
\hline African American & 0.06 & 1.07 & & 0.16 & 1.29 & & 0.10 & --- \\
\hline Hispanic & 0.03 & 0.84 & & 0.05 & 0.65 & & 0.06 & --- \\
\hline Education beyond Master's degree & 0.42 & 0.93 & & 0.43 & 0.89 & & 0.46 & --- \\
\hline Years of experience as principal & 9.31 & 1.00 & & 8.31 & 0.99 & & 9.12 & --- \\
\hline Years of experience as teacher & 13.91 & 1.00 & & 14.26 & 1.00 & & 14.06 & --- \\
\hline
\end{tabular}

Note: $* * p \leq 0.01, * * * p \leq 0.001$

principals had somewhat lower reported frequencies of attending to managerial tasks and transformational and instructional leadership behaviors, which were fairly close to the Integrating principal type. Yet, Controlling principals perceived their teachers as having the least amount of influence over managerial tasks and instructional leadership. This difference defines the Controlling group, in that the principals perceive that they practice leadership behaviors often themselves, but share the least amount of leadership in either managerial or instructional domains with their teachers. In contrast to these two groups, fewer Balkanizing principals reported weekly practice of managerial tasks, transformational and instructional leadership, yet reported a higher degree of teacher influence over managerial tasks and instructional leadership compared to Controlling principals. Balkanizing principals appear to be the opposite of the Controlling principals. For the group that we termed Balkanizing, these principals have the lowest frequencies of attending to transformational and instructional leadership (although the differences between the three groups on managerial tasks is fairly small, see Figure 2 left), but compare favorably to the Integrating principals in the degree of influence that the principals report that teachers have on school decisions that relate to managerial and instructional issues.
In addition to the survey responses that help to define the three latent classes, LCA allows for inclusion of independent variables in the omnibus model which test the extent that principal and school background variables predict the principal classes or types. Table 3 presents the results from this part of the model, and shows that the background variables significantly predict the principal types. Because the Integrating subgroup had the majority of the principals, we used this group as the reference group and present odds ratios in Table 3 that describe the odds of a principal being in either Balkanizing or Controlling in comparison to Integrating. Both Balkanizing and Controlling principals were less likely to meet district or state accountability goals compared to Integrating principals and less likely female. Specific to the Balkanizing type, these principals served in a school with fewer minority students, lower enrollment and were more often located in a rural area. These background variables help to further distinguish between the types.

Thus, our results demonstrate that the principal and school characteristics help to predict the three subgroups of principals and that these types significantly differ across the survey items in both their perceptions of their leadership style and their perceptions of the amount of influence teachers have over important managerial and instructional tasks in the school. In comparing our results with 


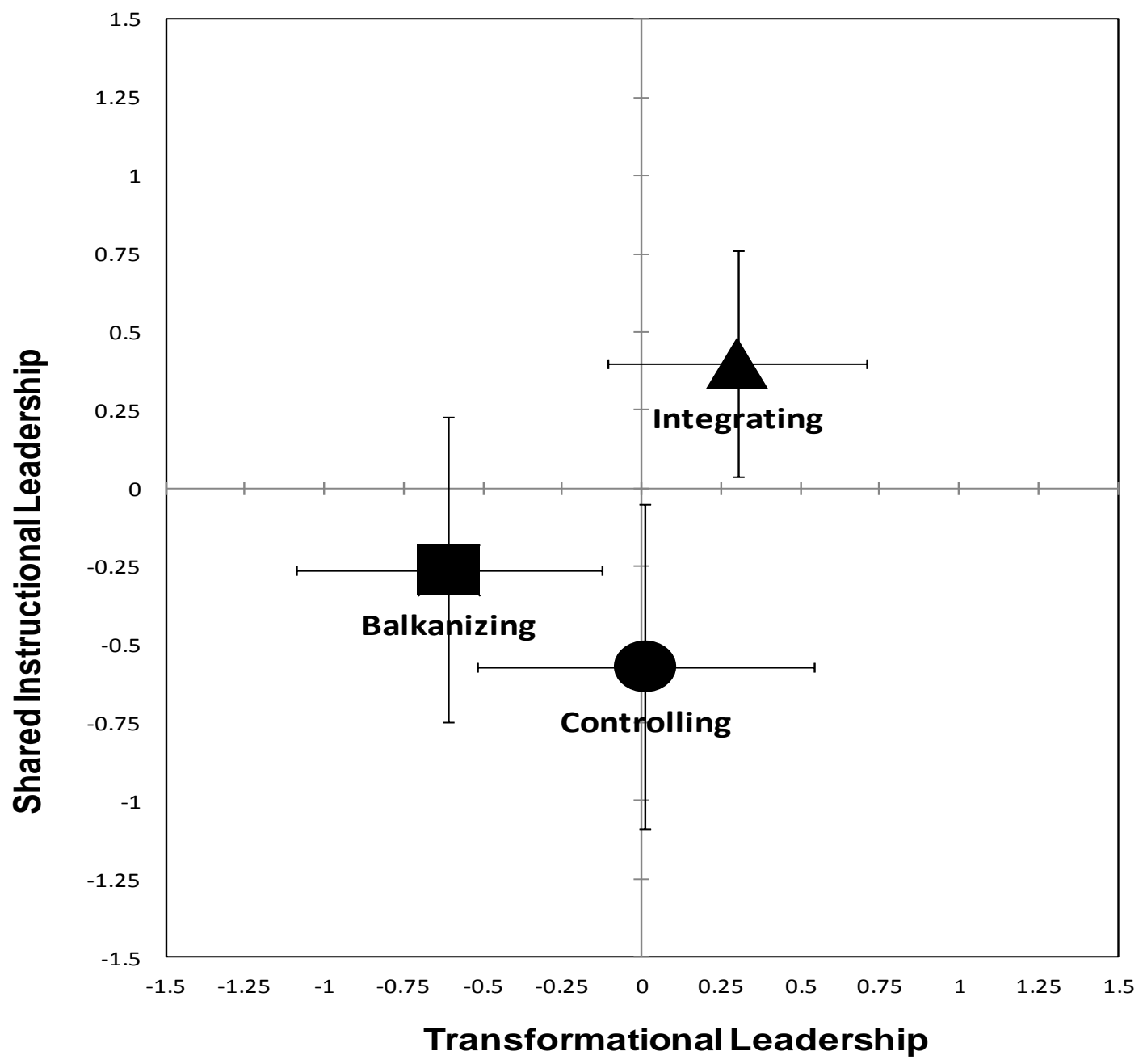

Figure 4: Plot of the relationship between transformational leadership and shared instructional leadership for each class using standardized mean scores of items that represent principal transformational leadership and teacher and principal instructional leadership. Error bars indicate $+/$ - one standard deviation in each dimension.

the past literature, such as Marks \& Printy (2003), we see this difference across the subgroups as lying along two dimensions, transformational leadership and shared instructional leadership. While we note that the Integrating, Balkanizing and Controlling principal types are identified by the differing patterns across Figures 2 and 3 above, the past literature (Marks \& Printy, 2003) has suggested that principals and schools may be simultaneously distributed along two dimensions of leadership, transformational leadership that focuses on principals engaging teachers in the organizational processes of the school, and shared instructional leadership, that focuses on principals distributing leadership tasks to teachers and building a synergy between themselves and teachers around issues with curriculum, instruction, pedagogy and professional development. Rather than describing principals and schools as either transformational or not, or shared instructional or not, Marks \& Printy (2003) urged for the integration of these concepts. They viewed their sample of 24 restructured schools from 1994 as distributing across both dimensions on continuous scales. This demonstrated that for their sample, no schools with low transformational leadership had high shared instructional leadership. Rather, the schools distributed across all other Urick \& Bowers (2014) quadrants, indicating that transformational leadership was necessary but insufficient for shared instructional leadership, at least in their limited sample of 24 restructured schools.

For the present study, we are able to test if the Marks \& Printy (2003) pattern holds in the large nationally generalizable SASS sample by answering, in what way do these different types of principals demonstrate a two dimensional relationship between transformational and shared instructional leadership?

Thus, to help visualize the differences across the three groups and test the postulates, standardized mean scores of principal transformational leadership items and principal and teacher instructional leadership items from the raw data were plotted for each type of principal in Figure 4. This figure synthesizes the information from Figures 2 and 3, by plotting the mean responses of each of the three subgroups using the mean across transformational leadership items from Figure 2 to represent the principals' engagement of teachers in the organization for the $\mathrm{x}$ axis, and the mean across instructional leadership items from both Figures 2 and 3 to represent the synergy between principal and 
teachers around instruction for the y-axis in Figure 4. Of note, in replicating and extending the work of Marks \& Printy (2003) to a large nationally generalizable sample, none of the centroids for any of the three subgroups fell within the upper left quadrant, providing substantial support for the hypothesis that transformational leadership is necessary but insufficient for shared instructional leadership.

In examining Figure 4, the centroid for Integrating principals in these two dimensions is in the upper right quadrant. These principals had high transformational leadership and high shared instructional leadership. Furthermore, the Integrating type had less variation (represented by length of error bars) in the practice of these styles of leadership compared to the other types. This indicates that Integrating principals perceived both high transformational and shared instructional practices. Interestingly, as noted above, the majority $(53.93 \%)$ of the principals were Integrating. Given that this is the first study to examine the prevalence of different types of principals as they relate to transformational and shared instructional leadership using a large nationally generalizable sample, our results indicate that the majority of principals in 1999-2000 reported that they perceived their schools as being high in both dimensions. The centroid for Controlling principals sits in the lower right quadrant with error bars extending across to the lower left quadrant. These principals had a mid-range practice of transformational leadership with low shared instructional leadership. Thus, because the results suggest that these principals perceived that they were leading their schools in management tasks, transformational and instructional leadership domains (see Figure 2), but that they were not distributing this leadership to their teachers (see Figure 3), we termed these principals "Controlling". The centroid for Balkanizing principals is situated in the lower left quadrant of Figure 4, which was low overall but somewhat between Integrating and Controlling in shared instructional leadership, but the lowest in transformational leadership among the three types. We termed these principals as "Balkanizing" since it appeared from their responses across the survey items that they had the lowest perceptions of their own leadership (see Figure 2), but reported that teachers had a high degree of influence over managerial and instructional tasks (see Figure 3). Thus it appears that these principals promoted a "Balkanizing" form of leadership, in which they ceded leadership authority to teachers and teacher teams. This hypothesis is supported by the significant background variables as predictors, in that Balkanized principals were likely to be in small, rural schools where principals might have felt that more frequent centralized leadership was not as necessary since fewer teachers fulfilled many different roles. While these findings appear intuitive to principals in guiding a particular school's structure, there has been little previous evidence to suggest which leadership behaviors and context variables define the difference between principals.

\section{DISCUSSION}

This study is novel and significant for three main reasons. First, our results indicate for the first time in the literature that there are three significantly different types of U.S. principals which do not follow the pattern of separately defined leadership styles across previous literature. Second, the results of this study confirm that leadership styles are multidimensional with both transformational and shared instructional leadership describing the found principal types previously argued by Marks and Printy (2003). Third, these findings highlight important school context factors that help to predict the ways in which principals are most likely leading a particular school. For the first time, this study identifies three significantly different types of principals across the U.S. while appropriately accounting for school context and principal background.

A long history of educational leadership research has utilized leadership styles to define different types of leaders (Robinson, Lloyd \& Rowe, 2008). However, few studies have used measures of several leadership styles under the assumption that multiple leadership styles simultaneously have a positive influence on outcomes (e.g. Bogler, 2001). The present study demonstrated with the description of three different types of principals, Balkanizing, Controlling and Integrating, that principals enact several different leadership styles in their role as a school leader. Balkanizing, Controlling and Integrating principals had a relatively high number of responses that they practiced managerial tasks - transactional leadership (Bass, 1985; Firestone \& Wilson, 1985). Both Controlling and Integrating principals responded that they practiced transformational and instructional leadership frequently. Yet, compared to Integrating and Balkanized principals, Controlling principals less often shared managerial or instructional leadership tasks with teachers. Knowing that principals use several leadership styles within their role, future research that attempts to measure the extent of principal influence on outcomes should focus on measuring their leadership using a set of core behaviors (see Hargreaves, Halász \& Pont, 2007; Hopkins \& Higham, 2007; Ishimaru, 2012; Leithwood, Harris \& Hopkins, 2008; Leithwood, Patten \& Jantzi, 2010; Robinson, Lloyd \& Rowe, 2008; Ylimaki \& Jacobson, 2013) or multiple leadership styles in order to capture a complete range of leadership tasks rather than limiting principal behavior to individual leadership styles. If the intent of future research is to further describe the ways in which principals or teachers vary across schools using a chosen set of behaviors, then latent class analysis or mixture models would help to identify types of educators and describe the different ways in which tasks are multidimensional, or simultaneously performed between the types.

In order to connect this typology with previous literature, we examined the relationship between transformational and shared instructional leadership for each type of principal to confirm the prior finding that only schools with high transformational leadership practiced high shared instructional leadership (Marks \& Printy, 2003). Using nationally representative data, we confirmed that Integrating principals practiced both high transformational and high shared instructional leadership as postulated by Marks and Printy (2003). In addition, we showed that Controlling principals had mid-level transformational leadership and low shared instructional leadership, and Balkanizing principals had slightly higher shared instructional leadership compared to Controlling principals, but less transformational leadership. Neither centroid for Balkanizing nor Controlling was situated within the middle of a positive quadrant indicating that their transformational and shared instructional leadership were both low in comparison to Integrating principals. In the Marks and Printy (2003) study, the schools without integrated leadership were described as either: not having a principal, having a new or interim principal, or not sharing instructional decisions with teachers, but sharing other leadership tasks with teachers. In contrast to Marks and Printy (2003), we found that Balkanizing principals ceded both instructional and managerial leadership to teachers, whereas Controlling principals more often withheld leadership from teachers. These relatively lower school leader types were best predicted by their school's structural characteristics, such as school size, location, whether or not the school met district or state accountability standards as well as principal gender, which influenced their perception of their own 
leadership behaviors or style. We recommend that future studies test the directional relationship between leadership styles, managerial, transformational, instructional and shared instructional, as well as these types, Controlling, Balkanizing and Integrating to demonstrate the development of a principals' perception or use of behaviors. An analysis of the directional relationship of leadership styles would demonstrate the extent that one set of behaviors predicts a subsequent set of behaviors, whereas the same test of types would show the probability of principals to transition from one type to the next.

Few studies have taken into account that leadership varies across schools based on the school context. To date, no study has utilized nationally representative data to demonstrate how school context helps us predict different types of principals across the U.S. Based on previous literature, we argue that principals mediate information about the school context, such as district accountability, teacher and student background etc., in order to assess how to direct their own leadership (see Bandura, 1982; Glasman \& Heck, 1992; Leithwood \& Jantzi, 2008; Leithwood et al., 2007; Portin et al., 2009; Spillane, 2006). With this information, principals formulate perceptions about which leadership behaviors will be successful, then create school conditions with their chosen leadership (Bandura, 1997; Leithwood \& Jantzi, 2008; Portin et al., 2009; Spillane, Camburn \& Pareja, 2007; Tschannen-Moran \& Gareis, 2007). This argument aligns with contingency theory which states that based on the situation, such as the task to be accomplished, and the composition of the group to perform the task, a leader selects whether to take a more task oriented, managerial, or controlled approach, or relationship oriented, transformational or shared approach (Fiedler, 1964; 1966; 1967). Rowan (1990) further explains:

...organic forms of management [such as shared
instructional leadership] may not enhance instructional
effectiveness across all conditions of classroom
organization. In fact, when the technology of instruction
is routinized, as it is in many behavioristic instructional
systems that have tightly specified curriculum
hierarchies and tie student progress to testing, a
mechanistic and control-oriented strategy may be
appropriate and lead to increased instructional
effectiveness (pp. 382-3).

Our assertion of a context-based leadership extends beyond correctly supporting teachers and effective instruction through either controlled or shared leadership (see Firestone \& Wilson, 1985; Rowan, 1990; Miller \& Rowan, 2006). Each characteristic of the school, students, teachers and principal influences a principal's leadership behavior in a different way (Goldring, Huff, May \& Camburn, 2007; Glasman \& Heck, 1992; Hallinger \& Murphy, 1986; Krüger, Witziers \& Sleegers, 2007; Mayrowetz, Murphy, Louis \& Smylie, 2007).

Integrating principals reported a higher number of faculty teaching to high academic standards and lower social disorder. These principals built a positive academic climate around high standards with fewer disciplinary issues. Further, Integrating principals were most often female and more often met state or district accountability goals. Balkanizing principals were often male in small, rural schools with fewer minority students and less often had and met state or district goals. This small, rural school context may have prompted the principal to cede leadership to teachers since there is a smaller staff that may perform multiple roles. In contrast, Controlling principals less often had and met state or district goals and were also male. Miller and Rowan (2006) argue that more organic forms of leadership, such as shared instructional leadership, does not always influence an increase in student achievement. Future research should test a mediated (Hallinger \& Heck, 1996) model of leadership and school and teacher conditions to examine whether or not these types of principals influence student success.

Thus, in conclusion we assert that the findings from our model help extend theory and practice at the intersection of principal perception, contingency theory and principal types over styles. Based on the results, we contend that the study of principal types with context as a significant predictor is an important extension of the current research. We found that the majority of the principals in the survey were of the Integrating type, who perceived their behaviors as distributing the leadership in the school while also providing an instructional focus and climate around which teachers have a mission, community and professional development. We replicate and extend the work of Marks \& Printy (2003) by demonstrating that there are principals who see themselves as ceding authority over the instructional core to the teachers while also maintaining a frequent centralized, transformational leadership. We distinguished between two types who perceived themselves as practicing transformational and shared instructional leadership in ways different than Integrating principals, or an idealized type. We encourage future research to explore why these principals self-reported less frequent leadership associated with these styles, or through the perception of themself and the school decided on a lesser degree or frequency of particular idealized leadership behaviors. Since principal perception is understudied, yet self-reported, we need more evidence to better understand how these principal types might have changed if teacher perception was also included in the model. We hypothesize that some of the observed difference may be due to context, and that a greater focus on these lower responder types would help inform future theory and research around best practices in schools, especially given the bulk of work to date around idealized styles discussed above. Additionally, future research should focus on identifying the extent to which these three types of leaders influence teacher practices and student learning. It may be that a specific type of leader is needed in some contexts, such as a Controlling principal in a school with extensive behavior problems, or a Balkanizing principal in a community in which multiple community stakeholders are in dispute over the mission of the school. We encourage future research to focus on these areas.

We recognize that our analysis was limited in the following ways. We used the 1999-2000 SASS because it provided a unique opportunity to test our theory using nationally representative data. Although we were able to include the most current conceptualizations of leadership, this data is over ten years old at the time of this writing. Since the passing of No Child Left Behind in 2001, the accountability climate in schools has changed. This increase in academic standards and testing may shift the membership across types or change the number and description of principal types. We attempted to account for the changing accountability context by including the have and met state or district goals as a control variable. In addition, no other study has demonstrated how principal perceptions of their leadership style group into principal types using nationally representative data. Future studies should use more recent data to confirm these results. 


\section{Recommended Citation:}

Urick, A., Bowers, A.J. (2014) What are the Different Types of Principals Across the U.S.? A Latent Class Analysis of Principal Perception of Leadership. Educational Administration Quarterly, 50(1), 96-134. doi:10.1177/0013161X13489019

\section{REFERENCES}

Bandura, A. (1997). Self-efficacy: The exercise of control. New York: W. H. Freeman and Company.

Bandura, A. (1982). Self-efficacy mechanism in human agency. American Psychologist, 37(2), 122-147.

Bass, B. (1985). Leadership and performance beyond expectations. New York: Free Press.

Bass, B., \& Avolio, B. (1990). Developing transformational leadership: 1992 and beyond. Journal of European Industrial Training, 14(5), 21-27.

Berliner, D. (1986). In pursuit of the expert pedagogue. Educational Researcher, 15(7), 5-13.

Blase, J., \& Blase, J. (1999). Principals' instructional leadership and teacher development: Teachers' perspectives. Educational Administration Quarterly, 35(3), 349-378.

Bogler, R. (2001). The influence of leadership style on teacher job satisfaction. Educational Administration Quarterly, 37, 662-683.

Bowers, A. J., \& Sprott, R. (2012a). Examining the multiple trajectories associated with dropping out of high school: A growth mixture model analysis. Journal of Educational Research, 105, 176-195. doi:10.1080/00220671.2011.552075

Bowers, A. J., \& Sprott, R. (2012b) Why tenth graders fail to finish high school: A dropout typology latent class analysis. Journal of Education for Students Placed at Risk (JESPAR), 17(3), 129-148. doi:10.1080/10824669.2012.692071

Boyd, D., Lankford, H., Loeb, S., \& Wyckoff, J. (2005). Explaining the short careers of high-achieving teachers in schools with low-performing students. The American Economic Review, 95(2), 166-171.

Bryk, A., Sebring, P., Allensworth, E., Luppescu, S., \& Easton, J. (2010). Organizing schools for improvement: Lessons from Chicago. Chicago, IL: The University of Chicago Press.

Bridges, E. (1967). A model for shared decision making in the school principalship. Educational Administration Quarterly, 3, 49-61.

Bass, B., \& Avolio, B. (1993). Transformational leadership: A response to critiques. In M. Chemers and R. Ayman (Eds.) Leadership theory and research: Perspectives and directions (pp. 49-80). San Diego, CA: Academic Press.

Burns, J. (1978). Leadership. New York: Harper \& Row.

Cuban, L. (1984). Transforming the frog into a prince: effective schools research, policy and practice at the district level. Harvard Educational Review, 54, 129-151.

Dolan, C. (2009). Structural equation mixture modeling. In R. Milsap \& A. Maydeu-Olivares (Eds.) The Sage handbook of quantitative methods in psychology (pp. 568-591). Thousand Oaks, CA: Sage Publications.

Dorman, J. (2003). Relationship between school and classroom environment and teacher burnout: A LISREL analysis. Social Psychology of Education, 6, 107-127.

Duncan, T., Duncan, S., \& Strycker, L. (2006). An introduction to latent variable growth curve modeling: Concepts, issues, and applications. Mahwah, New Jersey: Lawrence Erlbaum Associates.

Edmonds, R. (1979). Some schools work and more can. Social Policy, 17(5), 17-18.

Evans, A. (in press). Contributions of principal characteristics and school characteristics to principal self-efficacy.

Fiedler, F. (1967). A theory of leadership effectiveness. New York: McGraw Hill.

Fiedler, F. (1966). The effect of leadership and cultural heterogeneity on group performance: A test of the contingency model. Journal of Experimental Social Psychology, 2(3), 237-264.

Fiedler, F. (1964, 1978). A contingency model of leadership effectiveness. In L. Berkowitz (Eds.), Advances in experimental social psychology. New York: Academic Press.

Firestone, W., \& Wilson, B (1985). Using bureaucratic and cultural linkages to improve instruction: The principal's contribution. Educational Administration Quarterly, 21, 7-30.

Geijsel, F., Sleegers, P., Leithwood, K., \& Jantzi, D. (2003). Transformational leadership effects on teachers' commitment and effort toward school reform. Journal of Educational Administration, 41, 228-256.

Glasman, N., \& Heck, R. (1992). The changing leadership role of the principal: Implications for principal assessment. Peabody Journal of Education, 68, 5-24.

Goldring, E., Huff, J., May, H., \& Camburn, E. (2008). School context and individual characteristics: What influences principal practice? Journal of Educational Administration, 46(3), 332-350.

Goodman, L. (2002). Latent class analysis: The empirical study of latent types, latent variables, and latent structures. In J. Hagennaars and A. McCutcheon (Eds.) Applied latent class analysis (pp. 3-55). Cambridge, UK: Cambridge University Press.

Griffith, J. (1999). School climate as social order and social action: A multi-level analysis of public elementary school student perceptions. Social Psychology of Education. 2, 339-369.

Gruber, K., Wiley, S., Broughman, S., Strizek, G., \& BuranFitzgerald, M. (2002). Schools and Staffing Survey 19992000: Overview of the data for public, private, public charter and Bureau of Indian Affairs elementary and secondary schools. Washington DC: U.S. Department of Education, National Center for Educational Statistics, NCES 2002-313.

Guarino, C., Santibanez, L., \& Daley, G. (2006). Teacher recruitment and retention: A review of the recent empirical literature. Review of Educational Research, 76(2), 173-208.

Hallinger, P. (2005). Instructional leadership and the school principal: A passing fancy that refuses to fade away. Leadership and Policy in Schools, 4, 221-239.

Hallinger, P. (2003). Leading educational change: Reflections of the practice of instructional and transformational leadership. Cambridge Journal of Education, 33(3), 329350.

Hallinger, P., Bickman, L., Davis, K. (1996). School context, principal leadership, and student achievement. The Elementary School Journal, 96(5), 527-549.

Hallinger, P., \& Heck, R. (2010). Leadership for learning: Does collaborative leadership make a difference in school 
improvement. Educational Management and Administration \& Leadership, 38(6), 654-678.

Hallinger, P., \& Heck, R. (2011). Conceptual and methodological issues in studying school leadership effects as a reciprocal process. School Effectiveness School Improvement, 22, 149-173.

Hallinger, P., \& Heck, R. (2001). What do you call people with visions? The role of vision, mission and goals in school leadership and improvement. In K. Leithwood and P. Hallinger (Eds.) Second International Handbook of Educational Leadership and Administration (pp. 9-40). Great Britain: Kluwer Academic Publishers.

Hallinger, P., \& Heck, R. (1998). Exploring the principal's contribution to school effectiveness: 1980-1995. School Effectiveness and School Improvement, 9, 157-191.

Hallinger, P., \& Heck, R. (1996). Reassessing the principal's role in school effectiveness: A review of empirical research, 1980-1995. Educational Administration Quarterly, 32, 544.

Hallinger, P, \& Murphy, J. (1986). The social context of effective schools. American Journal of Education, 94, 328-355.

Hallinger, P., \& Murphy, J. (1985). Assessing the instructional leadership behavior of principals. Elementary School Journal, 86, 217-248.

Harris, A. (2004). Distributed leadership and school improvement: Leading or misleading? Educational Management, Administration and Leadership, 32, 11-24.

Harris, A., Leithwood, K., Day, C., Sammons, P., \& Hopkins, D. (2007). Distributed leadership and organizational change: Reviewing the evidence. Journal of Educational Change, 8, 337-347.

Heck, R. \& Hallinger, P. (2009). Assessing the contribution of distributed leadership to school improvement and growth in math achievement. American Educational Research Journal, 46, 659-689.

Hoy, W., \& Hannum, J. (1997). Middle school climate: An empirical assessment of organizational health and student achievement. Educational Administration Quarterly, 33, 290-311.

Hoy, W., Sweetland, S., \& Smith, P. (2002). Toward an organizational model of achievement in high schools: The significance of collective efficacy. Educational Administration Quarterly, 38, 77-93.

Hoy, W., Tarter, C. J., \& Bliss, J. (1990). Organizational climate, school health, and effectiveness: A comparative analysis. Educational Administration Quarterly, 26, 260-279.

Hoy, W., Tarter, C. J., \& Woolfolk Hoy, A. (2006). Academic optimism of schools: A force for student achievement. American Educational Research Journal, 43, 425-446.

Ingersoll, R. (2001). Teacher turnover and teacher shortages: An organizational analysis. American Educational Research Journal, 38(3), 499-534.

Jung, T., \& Wickrama, K. (2008). An introduction to latent class growth analysis and growth mixture modeling. Social and Personality Psychology Compass, 2, 302-317.

Krüger, M., Witziers, B., \& Sleegers, P. (2007). The impact of school leadership on school level factors: Validation of a causal model. School Effectiveness and School Improvement, 18(1), 1-20.

Leithwood, K. (1994). Leadership for school restructuring. Educational Administration Quarterly, 30, 498-518.

Leithwood, K., \& Jantzi, D. (2008). Linking leadership to student learning: The contribution of leader efficacy. Educational Administration Quarterly, 44, 496-528.
Leithwood, K., \& Jantzi, D. (2000). The effects of transformational leadership on organizational conditions and student engagement with school. Journal of Educational Administration, 38, 112-129.

Leithwood, K., \& Jantzi, D. (1999). Transformational school leadership effects: A replication. School Effectiveness and School Improvement, 10, 451-479.

Leithwood, K., Leonard, L., \& Sharratt, L. (1998). Conditions fostering organizational learning in schools. Educational Administration Quarterly, 34, 243-276.

Leithwood, K., \& Mascall, B. (2008). Collective leadership effects on student achievement. Educational Administration Quarterly, 44(4), 529-561.

Leithwood, K., Mascall, B., Strauss, T., Sacks, R., Memon, N., \& Yashkina, A. (2007). Distributing leadership to make schools smarter: Taking the ego out of the system. Leadership and Policy in Schools, 6, 37-67.

Leithwood, K., Patten, \& Jantzi, D. (2010). Testing a conception of how school leadership influences student learning. Educational Administration Quarterly, 46(5), 671-706.

Leithwood, K., \& Steinbach, R. (1995). Expert problem solving. Albany, NY: State University of New York Press.

Leithwood, K., \& Sun, J. (2012). The nature and effects of transformational school leadership: A meta-analytic review of unpublished research. Educational Administration Quarterly, 48, 387-423.

Lo, Y. (2005). Likelihood ration tests of the number of components in a normal mixture with unequal variances. Statistics \& Probability Letters, 71, 225-235.

Lo, Y., Mendell, N., \& Rubin, D. (2001). Testing the number of components in a normal mixture. Biometrika, 88(3), 767778.

Louis, K., Leithwood, K., Wahlstrom, K., Anderson, S., Michlin, M., Mascall, B., Gordon, M., Strauss, T., Thomas, E., \& Moore, S. (2010). Learning from leadership: Investigating the Links to Improved Student Learning. A final research report to the Wallace Foundation.

Mangin, M. (2007). Facilitating elementary principals' support for instructional teacher leadership. Educational Administration Quarterly, 43, 319-357.

Marks, H., \& Louis, K. (1999). Teacher empowerment and the capacity for organizational learning. Educational Administration Quarterly, 35, 707-750.

Marks, H., \& Nance, J. (2007). Contexts of accountability under systemic reform: Implications for principal influence on instruction and supervision. Educational Administration Quarterly, 43(3), 3-37.

Marks, H., \& Printy, S. (2003). Principal leadership and school performance: An integration of transformational and instructional leadership. Educational Administration Quarterly, 39, 370-397.

May, H., Huff, J., \& Goldring, E. (2012). A longitudinal study of principals' activities and student performance. School Effectiveness and School Improvement, 23(4), 417-439.

Mayrowetz, D. (2008). Making sense of distributed leadership: Exploring the multiple usages of the concept in the field. Educational Administration Quarterly, 44, 424-435.

Mayrowetz, D., Murphy, J., Louis, K., \& Smylie, M. (2007). Distributed leadership as work redesign: Retrofitting the job characteristics model. Leadership and Policy in Schools, 6, 69-101.

McCutcheon, A. (1987). Latent class analysis. Newbury Park, CA: Sage. 
Miller, R., \& Rowan, B. (2006). Effects of organic management on student achievement. American Educational Research Journal, 43(2), 219-253.

Moolenaar, N., Daly, A., \& Sleegers, P. (2010). Occupying the principal position: Examining relationships between transformational leadership, social network position, and schools' innovative climate. Educational Administration Quarterly, 46, 623-670.

Muijs, D., \& Harris, A. (2003). Teacher leadership: A review of the literature. Educational Management \& Administration, 34, 437-449.

Muthén, B. (2002). Beyond SEM: General latent variable modeling. Behaviormetrika, 29(1), 81-117.

Muthén, B. (2003). Statistical and substantive checking in growth mixture modeling: Comment on Bauer and Curran. Psychological Methods, 8(3), 369-377.

Muthén, B. (2004). Latent variable analysis: Growth mixture modeling and related techniques for longitudinal data. In D. Kaplan (Ed.) The Sage Handbook of Quantitative Methodology for the Social Sciences. Thousand Oaks, CA: Sage (pp. 345-368).

Muthén, B. (2008). Latent variable hybrids: Overview of old and new models. In G. Hancock \& K. Samuelsen (Eds.) Advances in Latent Variable Mixture Models. Charlotte, NC: Information Age Publishing, pp. 1-24.

Muthén, B., \& Asparouhov, T. (2006). Item response mixture modeling: Application to tobacco dependence criteria. Addictive Behaviors, 31, 1050-1066.

Muthén, B., \& Muthén, L. (2000). Integrating person-centered and variable-centered analysis: Growth mixture modeling with latent trajectory classes. Alcoholism Clinical and Experimental Research, 24(6), 882-891.

Muthén, L., \& Muthén, B. (1998-2010). Mplus users guide (6 ${ }^{\text {th }}$ ed.). Los Angeles, CA: Muthén \& Muthén.

National Center for Educational Statistics (NCES). (n.d.). Schools and Staffing Survey. From http://nces.ed.gov/surveys/sass/.

Nguni, S., Sleegers, P., \& Denessen, E. (2006). Transformational and transactional leadership effects on teachers' job satisfaction, organizational commitment, and organizational citizenship behavior in primary schools: The Tanzanian case. School Effectiveness and School Improvement, 17, 145-177.

Nylund, K., Asparouhov, T., \& Muthen, B. (2007). Deciding on the number of classes in latent class analysis and growth mixture modeling: A monte carlo simulation study. Structural Equation Modeling, 14(4), 535-569.

Nylund, K., Bellmore, A., Nishina, A., \& Graham, S. (2007). Subtypes, severity, and structural stability of peer victimization: What does latent class analysis say? Child Development, 78(6), 1706-1722.

Portin, B., Knapp, M., Dareff, S., Feldman, S., Russell, F., Samuelson, C., \& Yeh, T. (2009). Leadership for learning improvement in urban schools. Center for the Study of Teaching and Policy. University of Washington. A report to the Wallace Foundation.

Printy, S. (2008). Leadership for teacher learning: A community of practice perspective. Educational Administration Quarterly, 44(2), 187-226.

Printy, S., Marks, H., \& Bowers, A. J. (2009). Integrated leadership: How principals and teachers share transformational and instructional influence. Journal of School Leadership, 19, 504-532.
Robinson, V., Lloyd, C., \& Rowe, K. (2008). The impact of leadership on student outcomes: An analysis of the differential effects of leadership types. Educational Administration Quarterly, 44, 635-674.

Rowan, B. (1990). Commitment and Control: Alternative strategies for the organizational design of schools. Review of Research in Education, 16, 353-389.

Slater, L. (2008). Pathways to building leadership capacity. Educational Management Administration \& Leadership, 36, 55-69.

Slater, R., \& Teddlie, C. (1992). Toward a theory of school effectiveness. School Effectiveness and School Improvement, 3(4), 242-257.

Smylie, M., \& Brownlee-Conyers, J. (1992). Teacher leaders and their principals: Exploring the development of new working relationships. Educational Administration Quarterly, 28, 150-184.

Somech, A. (2005). Directive versus participative leadership: Two complementary approaches to managing school effectiveness. Educational Administration Quarterly, 41(5), 777-800.

Spillane, J. (2006). Distributed leadership. San Francisco, CA: Jossey-Bass.

Spillane, J., Camburn, E., \& Pareja, A. (2007). Taking a distributed perspective to the school principal's workday. Leadership and Policy in Schools, 6, 103-125.

Spillane, J., Hallett, T., \& Diamond, J. (2003). Forms of capital and the constructional of leadership: Instructional leadership in urban elementary schools. Sociology of Education, 76, 1-17.

Spillane, J., Halverson, R., \& Diamond, J. (2004). Toward a theory of leadership practice: A distributed perspective. Journal of Curriculum Studies, 36, 3-34.

Stapleton, L. M. (2002). The incorporation of sample weights into multilevel structural equation models. Structural Equation Modeling, 9(4), 475-502.

Strayhorn, T. (2009). Accessing and analyzing national databases. In T. J. Kowalski and T. J. Lasley (Eds.) Handbook of data-based decision making in education. New York, NY: Taylor and Francis (pp. 105-122).

Supovitz, J., Sirindes, P., \& May, H. (2010). How principals and peers influence teaching and learning. Educational Administration Quarterly, 46(1), 31-56.

Thoonen, E., Sleegers, P., Oort, F., Peetsma, T, Geijsel, F. (2011). How to improve teaching practices: The role of teacher motivation, organizational factors, and leadership practices. Educational Administration Quarterly, 47, 496-536.

Tschannen-Moran, M., \& Gareis, C. R. (2007). Cultivating principals' self-efficacy: Supports that matter. Journal of School Leadership, 17, 89-114.

Urick, A. (2012). To what extent do typologies of school leaders across the U.S. predict teacher attrition? A multilevel latent class analysis of principals and teachers (Unpublished dissertation). (ERIC ID No. ED541342) http://eric.ed.gov/?id=ED541342

Urick, A., \& Bowers, A. J. (2011). What influences principals' perceptions of academic climate? A nationally representative study of the direct effects of perception on climate. Leadership and Policy in Schools, 10, 322-348. doi:10.1080/15700763.2011.57792 
Urick, A., Bowers, A.J. (2014) How does Principal Perception of Academic Climate Measure Up? The Impact of Principal Perceptions on Student Academic Climate and Achievement in High School. Journal of School Leadership, 24(2), 386-414.

Ware, H., \& Kitsantas, A. (2011). Predicting teacher commitment using principal and teacher efficacy variables: A HLM approach. The Journal of Educational Research, 104(3), 183-193.

Ware, H., \& Kitsantas, A. (2007). Teacher and collective efficacy beliefs as predictors of professional commitment. Journal of Educational Research, 100(5), 303-310.

Weathers, J. (2011). Teacher community in urban elementary schools: The role of leadership and bureaucratic accountability. Education Policy Analysis Archives, 19(3), 1-39.

Werblow, J., Urick, A., \& Duesbery, L. (2013). On the wrong track: How tracking is associated with dropping out of high school. Equity and Excellence in Education, 46, 270-284. doi:10.1080/10665684.2013.779168

Weiss, C. (1993). Shared decision making about what? A comparison of schools with and without teacher participation. Teacher College Record, 95, 69-92.

White, B., \& Bowers, A. J. (2011). Principal effects in Illinois: A research brief (IERC 2011-3). Edwardsville: Illinois Education Research Council, Southern Illinois University Edwardsville. Retrieved from http://www.siue.edu/ierc/publications/pdf/20113_Principal_Effects.pdf
Wolfe, E., Ray, L., \& Harris, D. (2004). A Rasch analysis of three measures of teacher perception generated from the schools and staffing survey. Educational and Psychological Measurement, 64(5), 842-860.

Zembylas, M., \& Papanastasiou, E. (2005). Modeling teacher empowerment: The role of job satisfaction. Educational Research and Evaluation, 11(5), 433-459.

Zigarelli, M. (1996). An empirical test of conclusions from effective schools research. The Journal of Educational Research, 90(2), 103-110.

\section{About the Authors:}

Angela Urick is an assistant professor in the Jeannine Rainbolt College of Education, Department of Educational Leadership and Policy Studies, at the University of Oklahoma. Her research interests include principal and teacher perceptions of leadership, leadership styles, school climate, teacher retention, and school improvement.

Alex J. Bowers is an associate professor of education leadership at Teachers College, Columbia University. His research interests include organizational behavior, district effectiveness, data-driven decision making, school and district leadership, educational assessment and accountability, student dropout and at-risk identification, school leadership preparation, student and school technology use, and K-12 school facilities funding. ORCID: 00000002-5140-6428, ResearcherID: C-1557-2013. 


\section{Appendix}

Appendix 1: Descriptives of dichotomous variables from model sample

\begin{tabular}{lccccc}
\hline Variable & SASS Variable & Min & Max & Mean & SD \\
\hline Principal Leadership & & & & & \\
Transactional Leadership & & & & & \\
Maintain physical security & A0204 & 0 & 1 & 0.94 & 0.23 \\
Manage school facilities & A0205 & 0 & 1 & 0.94 & 0.23 \\
Supervise staff & A0198 & 0 & 1 & 0.84 & 0.37 \\
Attend district meetings & A0206 & 0 & 1 & 0.56 & 0.50 \\
& & & & & \\
Transformational Leadership & & & & & \\
Attend prof dev with teachers & A0163 & 0 & 1 & 0.90 & 0.30 \\
Develop public relations & A0203 & 0 & 1 & 0.74 & 0.44 \\
Facilitate achvment of school mission & A0197 & 0 & 1 & 0.70 & 0.46 \\
Build professional community & A0202 & 0 & 1 & 0.66 & 0.47 \\
Provide prof dev activities & A0201 & 0 & 1 & 0.37 & 0.48 \\
& & & & & \\
Instructional Leadership & & & & & \\
Guide development of curriculum & A0199 & 0 & 1 & 0.63 & 0.48 \\
Facilitate student learning & A0200 & 0 & 1 & 0.81 & 0.39 \\
\hline
\end{tabular}

Appendix 2: Descriptives of continuous variables from model sample

\begin{tabular}{lcccccc}
\hline Variable & SASS Variable & Min & Max & $n$ & Mean & SD \\
\hline $\begin{array}{l}\text { Percent of teachers teaching to high } \\
\text { academic standards }\end{array}$ & A0173 & 0 & 100 & 7650 & 78.62 & 18.52 \\
Principal perception of social disorder & $\begin{array}{c}\text { Mean of A0130- } \\
1,133-6,138-\end{array}$ & 0 & 2.80 & 7650 & 0.84 & 0.47 \\
& $141, \alpha=.85$ & & & & & \\
& & & & & & \\
Shared Leadership with Teachers & & & & & & \\
Transactional Leadership & A0105 & 0 & 4 & 7650 & 2.06 & 1.23 \\
Evaluation of teachers & A0112 & 0 & 4 & 7650 & 2.30 & 1.23 \\
Hiring of teachers & A0127 & 0 & 4 & 7650 & 2.54 & 1.08 \\
Spending & A0119 & 0 & 4 & 7650 & 3.22 & 0.86 \\
Discipline policy & & & & & & \\
Instructional Leadership & A0081 & 0 & 4 & 7650 & 3.04 & 0.95 \\
Performance standards & A0089 & 0 & 4 & 7650 & 3.09 & 0.92 \\
Curriculum & A0097 & 0 & 4 & 7650 & 3.08 & 0.90 \\
Prof dev program for teachers & & & &
\end{tabular}


Appendix 3: Descriptives of school and principal background variables from model sample

\begin{tabular}{|c|c|c|c|c|c|}
\hline Variable & SASS Variable & Min & $\operatorname{Max}$ & Mean & $S D$ \\
\hline \multicolumn{6}{|l|}{ School Demographics } \\
\hline Urban & URBANIC, $1=$ Urban & 0 & 1 & 0.22 & 0.41 \\
\hline Rural & URBANIC, $1=$ Rural & 0 & 1 & 0.40 & 0.50 \\
\hline Small enrollment & $\begin{array}{l}\text { S0101, } \\
1=1-599 \text { students }\end{array}$ & 0 & 1 & 0.60 & 0.50 \\
\hline Large enrollment & $\begin{array}{l}\text { S0101, } \\
1=1201-1800 \text { students }\end{array}$ & 0 & 1 & 0.08 & 0.27 \\
\hline Extra large enrollment & $\begin{array}{l}\text { S0101, } \\
1 \geq 1801 \text { students }\end{array}$ & 0 & 1 & 0.05 & 0.21 \\
\hline Elementary level & $\begin{array}{l}\text { SCHLEVE2, } \\
\text { 1=Elementary }\end{array}$ & 0 & 1 & 0.40 & 0.50 \\
\hline Percent of students with IEP & IEP & 0 & 100 & 14.27 & 15.00 \\
\hline Percent of ELL students & LEP & 0 & 100 & 4.70 & 13.06 \\
\hline Percent of students eligible for FRPL & S0284, S0101 & 0 & 100 & 40.73 & 28.24 \\
\hline Percent of minority students & MINENR & 0 & 100 & 30.93 & 32.14 \\
\hline Percent of minority teachers & MINTCH & 0 & 100 & 14.14 & 22.84 \\
\hline Student/teacher ratio & STU_TCH & 0.56 & 745.60 & 15.03 & 9.53 \\
\hline School met district or state goals & PRFMET & 0 & 1 & 0.59 & 0.49 \\
\hline \multicolumn{6}{|l|}{ Principal Background } \\
\hline Female & A0227, 1=Female & 0 & 1 & 0.35 & 0.48 \\
\hline Asian & RACETH_P, $1=$ Asian & 0 & 1 & 0.01 & 0.11 \\
\hline African American & $\begin{array}{l}\text { RACETH_P, } \\
\text { 1=African American }\end{array}$ & 0 & 1 & 0.10 & 0.30 \\
\hline Hispanic & $\begin{array}{l}\text { RACETH_P, } \\
\text { 1=Hispanic }\end{array}$ & 0 & 1 & 0.04 & 0.20 \\
\hline Degree beyond Master's degree & A0225 & 0 & 1 & 0.44 & 0.50 \\
\hline Years of principal experience & PRNEXPER & 0 & 67 & 8.90 & 7.73 \\
\hline Years of teaching experience & TCHEXPER & 0 & 42 & 14.00 & 7.34 \\
\hline
\end{tabular}

